Article

\title{
Sustainability Goals and Firm Behaviours: A Multi-Criteria Approach on Italian Agro-Food Sector
}

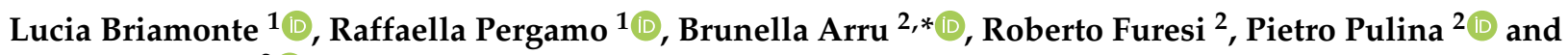 \\ Fabio A. Madau ${ }^{2} \mathbb{D}$ \\ 1 CREA-PB, 00198 Rome, Italy; lucia.briamonte@crea.gov.it (L.B.); raffaella.pergamo@crea.gov.it (R.P.) \\ 2 Department of Agriculture, University of Sassari, 07100 Sassari, Italy; rfuresi@uniss.it (R.F.); \\ ppulina@uniss.it (P.P.); famadau@uniss.it (F.A.M.) \\ * Correspondence: brarru@uniss.it
}

check for updates

Citation: Briamonte, L.; Pergamo, R.; Arru, B.; Furesi, R.; Pulina, P.; Madau, F.A. Sustainability Goals and Firm Behaviours: A Multi-Criteria Approach on Italian Agro-Food Sector. Sustainability 2021, 13, 5589. https://doi.org/10.3390/su13105589

Academic Editors:

Margarita Martinez-Nuñez and Ma Pilar Latorre-Martínez

Received: 22 March 2021

Accepted: 14 May 2021

Published: 17 May 2021

Publisher's Note: MDPI stays neutral with regard to jurisdictional claims in published maps and institutional affiliations.

Copyright: (c) 2021 by the authors. Licensee MDPI, Basel, Switzerland. This article is an open access article distributed under the terms and conditions of the Creative Commons Attribution (CC BY) license (https:// creativecommons.org/licenses/by/ $4.0 /)$.

\begin{abstract}
Today, the transition to a more sustainable model of the agro-food system is increasingly impellent, requiring all actors' commitment. In particular, small and medium agro-food business (SMABs) play a decisive and central role in the food and economies of national and underdeveloped areas. Our study aims to identify, through desk research, the level of commitment and communication to the sustainability of SMABs operating in southern Italy. In this study, we followed the Food and Agriculture Organization's (FAO) approach to implementing such a transition, using their principles as a diagnostic tool to interpret business operations. The data were analysed using two approaches: a regime analysis to assess which FAO principles are commonly followed to make the above transition possible, and an extension of the Abraham and Pingali (2020) framework to describe the commitment of SMABs to the Agenda 2030 goals with respect to the behaviour of small and medium enterprises (SMEs). We found that the SMABs' behaviours are more oriented towards some FAO principles: those that explain their commitment to improving natural resources and livelihoods, fostering inclusive economic growth, and achieving sustainable development goal 7 of Agenda 2030 than towards others. The contribution of our study lies in providing detailed insights into sustainable actions taken by SMABs while testing the FAO's principles as a new model to evaluate business operations.
\end{abstract}

Keywords: agro-food business; small and medium enterprise (SME); Food and Agriculture Organization (FAO); Agenda 2030; regime analysis

\section{Introduction}

Global food challenges in the 21st century require substantive changes in agriculture and the food system. These challenges are accelerating the transition to sustainable food and agriculture (SFA) to enable world food security and healthier diets, societal well-being, and environmental safeguards [1].

SFA is at the centre of the 2030 Agenda, which, in shifting the debate from 'willingness' to 'the ability to act', aims to spur people and institutions to an urgent rethinking of the global development model. In this vein, the Food and Agriculture Organisation (FAO) [2] has also developed a vision for SFA based on five principles which are aimed at providing a basis for developing policies, strategies, regulations, and incentives that enable SFA and rural development: (1) increasing the productivity, employment, and value addition in food systems; (2) protecting and enhancing natural ecosystems; (3) improving livelihoods and fostering inclusive economic growth; (4) enhancing the resilience of people, communities, and ecosystems, and (5) adapting governance to new challenges. Twenty interconnected actions, which countries together with key stakeholders should take to accelerate the transition to SFA, are derived from these principles. Moreover, these 20 practical and interconnected FAO actions, in addiction to aiming to transform food and agriculture, intend to drive achievement across the sustainable development goals (SDGs) of Agenda 2030 [2]. In effect, FAO plays a critical role in the 2030 Agenda [3] and FAO's strategic 
framework is explicitly aligned with the SDGs [4]. This is why FAO punctually indicates for each action which the SDGs are on which a contribution is made [2]. Evidence on business behaviours undertaken along the interlinks among FAO's actions and SDGs allow one to display whether and how the agri-food sector contributes to achieving sustainable development according to the Agenda 2030 [4].

Among the agents of SFA transition, the agriculture and agro-food business (hereinafter AFBs) play an essential role in improving and revitalising rural contexts [5], responding to a growing world population's food demand, and fostering inclusive growth; these are the cornerstones of the success of Agenda 2030 [6]. In particular, the role of SMABs, as well as of families and smallholders, has become increasingly more decisive, being the backbone of many rural societies, promoting innovation, and playing a central role in national food and economies [7-11].

Against this background, the transition to SFA from conventional unsustainable food practices requires the consideration of pivotal interlinks among the incomes of family and smallholder farms, sustainable practices, improved productivity, and technological innovation and efficiency across the sector [12-17].

This is also the approach of the European Green Deal, which calls on the European farmers and AFBs to re-adjust their work practices to the new green objectives (EU COM/2019/640 final; EU COM/2020/381). In effect, the European Green Deal, with the 'Farm to Fork' and 'Biodiversity' strategies and a reformed Common Agricultural Policy (CAP), aims to switch Europe's agricultural sector towards a more sustainable model, ensuring food security and the preservation of environmental and human health and making the EU the first climate-neutral continent in the world. The CAP and European Green Deal objectives' achievement requires that the entire agro-food sector (farms, agro-food industry, and organisations), which is known to be one of the main drivers of the EU economy [18], is involved in the changing process.

However, wanting to get upstream of the speech, although the European Green Deal is Europe's new growth strategy to transform the EU economy for a sustainable future, we need to refer first of all to the Agenda 2030 program, which also includes some of the strategic objectives of the CAP, and that is "the cornerstone of defining EU policies and interventions" [19] (p. 9). This is why Agenda 2030 is the ideal strategic framework for addressing the issue of sustainability for investigating AFBs.

In Italy, within a few years, many AFBs have been initiated that pursue social, environmental, and economic sustainability goals; Italy ranks third (preceded by Israel and Spain) at the international level in terms of sustainable agro-food start-ups [20]. These start-ups aim for innovative solutions for implementing more efficient use of resources, introducing the 'short supply chain', and using natural materials in production. The Italian agro-food system has shown progressive advancement and a good capacity for the sustainable management of agricultural resources [21]. Moreover, Italy's civil, social, and political traditions have contributed over time to an orientation towards sustainable entrepreneurship, fostered by a positive bond with the territory and the environment, along with a high level of social cohesion and stakeholders' proximity [22]. Within this context, SMEs, considered the backbone of the Italian economy, epitomise the entrepreneurs' ethical values that lead to adopting sustainability practices and strategies and contributing to sustainable development [22,23].

However, Italy has prominent differences between its north and south. South Italy is one of the EU's most underdeveloped areas and has a lower gross domestic product (GDP) and industrialisation rate than the peninsula. According to ISMEA, "in the South, the agri-food sector assumes greater economic importance than the Italian average and the rest of the country [ . . , and] the agri-food chain is an important production pillar in the South" [24] (p. 37). Previous studies have shown that commitment to sustainability provides SMEs with competitive advantages, creating new market access, aligning activities with shifting customer preferences, capitalising on innovative solutions, filling market gaps due to market failure, and addressing economic disequilibria [8,25-27]. In this sense, 
the recovery of competitiveness of the agro-food sector of southern Italy must take place through the transition towards a sustainable AFB model to address this region's economic backwardness.

Based on these considerations, investigating the level of commitment and communication to sustainability among southern Italian SMABs is an important research topic.

Our study contributes to addressing this topic by diagnosing the current sustainability objectives mainly promoted by the southern Italian SMABS as well as analysing the issues that need to be addressed to achieve a higher level of sustainability. Specifically, a qualitative analysis was carried out to assess the FAO's principles and actions [2] towards which the sustainability practices of southern Italy's SMABs tend to be the most commonly oriented. Another contribution of this study is to present the FAO's principles as a diagnostic tool for evaluating business operations.

Furthermore, since FAO [2] links each action to several SDGs of the 2030 Agenda, we analysed the sustainable behaviours of SMABs also from the SDG point of view, adapting the Abraham and Pingali framework [28].

To our knowledge, this is the first study that has highlighted SMABs' behaviour regarding their compliance with the sustainability principles of the FAO. Moreover, as far as we know, this is the first study that uses the Abraham and Pingali framework [28] to look into the compliance of SMABs' behaviours with the SDGs in light of the specificities of the agro-food sector.

Our results can be a good starting point for future discussions on actions to be taken to improve SMABs competitiveness in this macro area.

\section{Methodology}

\subsection{Data Source}

The analysis presented in this study was carried out using a qualitative research approach, focusing on the SMABs operating in southern Italy. The firms' data were selected from the AIDA database (the Bureau van Dijk), which offers financial, demographic, and commercial information on Italian firms. Before selection, the firms were screened for the following criteria:

- Employees: a minimum of 10 (micro-businesses excluded);

- Legal status: active and viable;

- Availability of an official website.

A total of 720 Italian firms were selected. The research was carried out in July 2019 through a two-phase analysis of each firm's website.

First, we only selected the AFBs that have their own active websites, reducing the sample to 650 firms, of which 616 were SMABs. Then, companies that communicated one or more concrete actions (and not a simple declaration of intent) in line with the FAO's principles of sustainable food and agriculture actions were identified. This criterion helped to identify firms that implement and communicate sustainable actions in the field and not just state a commitment to sustainability. After applying these criteria, a total of 193 southern Italian firms were selected, of which 180 were SMABSs.

Websites were used as valid sources of data for several reasons. Communication plays a fundamental role and is an integral part of every sustainability plan or strategy [29]. In the case of AFBs, entered in the database consulted, the website, in addition to carrying out a communication function, also could refer to an idea of the web reputation of the company itself that can trace the picture of the main sustainable behaviours assumed over time and highlight the path taken.

Due to the growing demand from stakeholders for greater transparency, social and environmental responsibility, and dialogue, companies' awareness of the need to not only adopt sustainability activities but also inform their stakeholders about sustainability performance has grown, leading to constant growth in the size and complexity of communication on social and environmental issues [30]. 
Websites are the main communication channels for sustainable initiatives. They enable the communication of relevant information about the firms' commitment towards sustainable practice to a wider range of stakeholders than traditional media [31-33]. This is why many researchers chose companies' websites to measure their sustainability practices [34].

Our research focuses on SMABs' commitment towards sustainability. According to Hasim et al. (2018), 'commitment' can be understood as the extent of information provided by firms on their website, with demonstrated actions towards achieving sustainable development [35]. Moreover, due to the advantages offered by the Internet [36-38], websites are particularly appealing to SMEs because they mitigate traditional burdens related to firm size [39].

Therefore, this study considers website analyses as a legitimate research tool.

\subsection{Research Model}

The analysis focuses on assessing the ongoing sustainability behaviours mainly promoted by southern Italy's SMABs according to the five FAO principles stated in 'transforming food and agriculture to achieve the SDGs' [2] and the Agenda 2030 goals, bearing in mind the interlinks between the former and the latter. In effect, the FAO document [2] explains how each FAO action links multiple SDGs and integrates the three dimensions of sustainable development (economic, social, and environmental).

Regarding the five principles of FAO, although they are complementary, by highlighting the importance assigned to each one, it is possible to deepen which aspect is favoured by AFBs and offer considerations on the process of integrating sustainability targets into their practices. Moreover, we think that the analysis of the AFBs' behaviours according to the FAO principles and actions [2] is a suitable tool to overcome the limitations of the sustainability assessment of SMABs $[40,41]$.

In reference to the Agenda 2030-keeping in mind the pivotal role of the private sector in entrepreneurs' engagement and know-how transfer; job creation; and alternative revenue streams, and in particular, of the role of SMEs for the implementation of the 2030 agenda-we examined the agro-food SMEs' behaviours in light of the 17 sustainable development goals (SDGs) of Agenda 2030 according to the nature of the promoted actions of firms.

To this end, the Abraham and Pingali framework [28] was adapted. The authors offer a seminal paper that makes clear the link between the SDGs and the agri-food sector, with a particular focus on smallholder farming, identified which explicitly depend on firm growth for their achievement, and classified the SDGs that specifically pertain to the agricultural sector into four clusters: poverty goals, nutrition goals, social goals, and environmental goals. To look at the goals in the context of agro-food SMEs' behaviours, and considering the need to broaden the horizons from the agricultural sector to the agro-industrial one, the Abraham and Pingali clustering has been revisited, offering its evolved version, which includes all SDGs. The relevance of the SDGs not previously included in the Abraham and Pingali framework with the four clusters identified by the authors was assessed based on the content of the Agenda 2030, leading to the attribution of SDG 4 to the social cluster and of SDG7 and SDg14 to the environmental cluster. The SDGs 11, 16 and 17, not being directly attributable to one of the 4 clusters of the framework, were included in a new cluster named "residual cluster". This "extended framework" can produce a picture of SDGs' categories on which to act by stimulating, accelerating and supporting SMEs' behaviours to foster their transition to sustainable food and agriculture.

Figure 1 shows the existence of the link between the five FAO principles and the SDGs (which we have decided to analyse in light of the extended classification proposed by Abraham and Pingali [28]) and that SMABs' sustainable behaviour can be read in light of these two frameworks. 


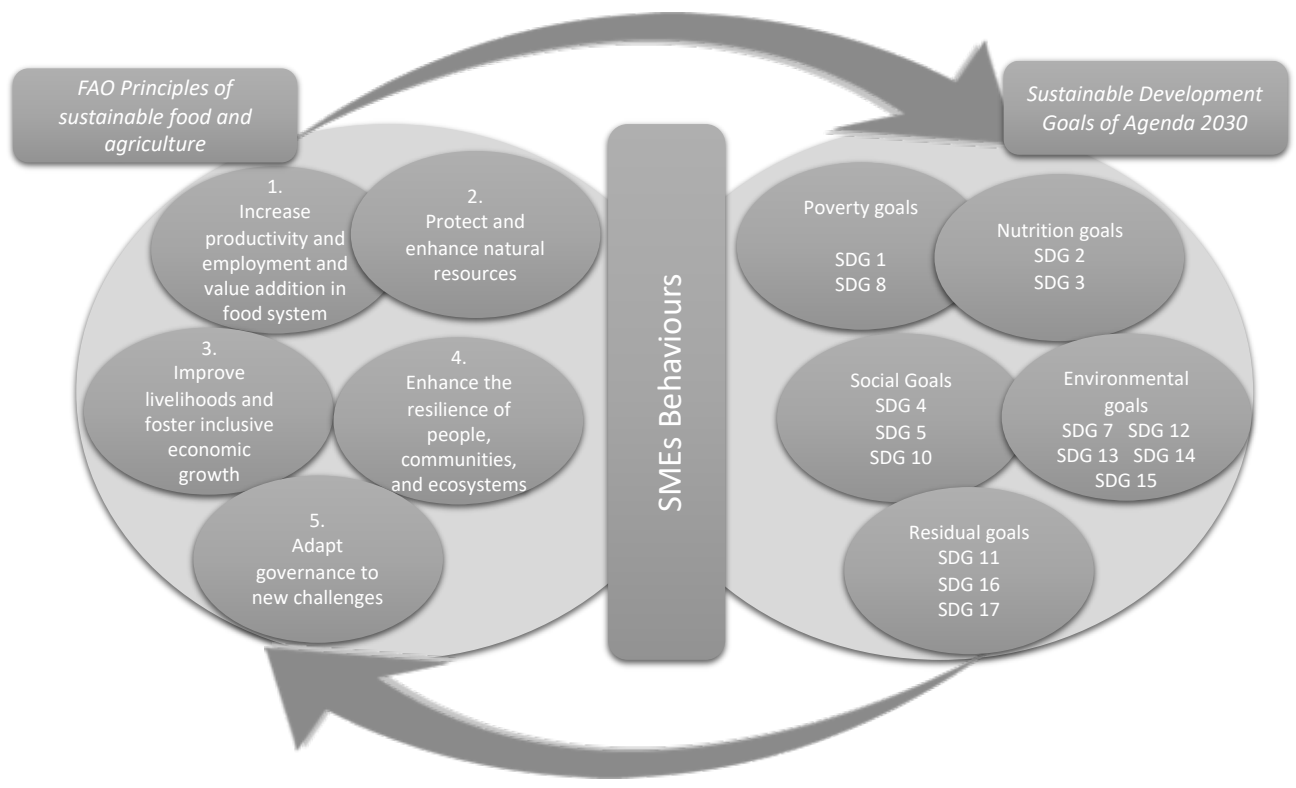

Figure 1. Research model.

\subsection{Method}

Given the exploratory character of this study and our research objectives, qualitative research was considered the most appropriate technique for analysing AFB behaviours' diversity. Qualitative research is gaining popularity in the small business and entrepreneurship research community [42]. It deals with non-numerical information, allowing the interpretation of a phenomenon and building a meaningful picture without compromising its richness and dimensionality [43].

Our qualitative analysis aimed at describing the diversity of sustainable behaviours of AFBs. Since the description of the diversity of characteristics of some topics of interest within a given population can be carried out using coding, the unidimensional description with downward coding [44] was deemed suitable for the purpose of our analysis. In effect, it involves organizing data into three logical levels of diversity; that is, objects, dimensions for each object and categories for each dimension, allowing us to move towards a lower level of abstraction [44]. Therefore, based on the unidimensional description of diversity proposed by Jansen [44], we analysed the diversity of sustainable behaviours of AFBs starting from the higher level of abstraction; that is, the sustainability behaviour of firms (the main object), following the middle level of abstraction; namely the FAO's principles and actions (the dimensions of objects), down to the lower abstraction level analysis consisting of the SDGs to which each FAO's action contributes (the categories of objects). It is important to highlight that the identification of SDGs relevant to each principle and actions FAO was made based on the explicit links indicated by FAO [2]). This articulation is indicated in Figure 2.

A chart with double entries was used to grasp each company's behaviour according to the three logical levels of diversity (Figure 3).

The vertical reading of the blue columns of the chart makes it possible to highlight each company's behaviour concerning the $5 \mathrm{FAO}$ principles and their respective actions (the last two lines of the blue cells). It concerns the analysis of the "dimensions of the object" that has been extended to all AFBs to offer an overview of the overall scenario of the agro-food sector in southern Italy.

To analyse the categories of dimensions (each company's behaviours concerning each FAO principles and actions respects to SDGs), based on the FAO document [2], the SDGs on which each FAO action has an impact were first identified. These interlinks are signalled with green cells in the chart. Each green cell allows a dichotomous response variable (yes/no). The sum of the "yes" is shown in the cells of the totals. 


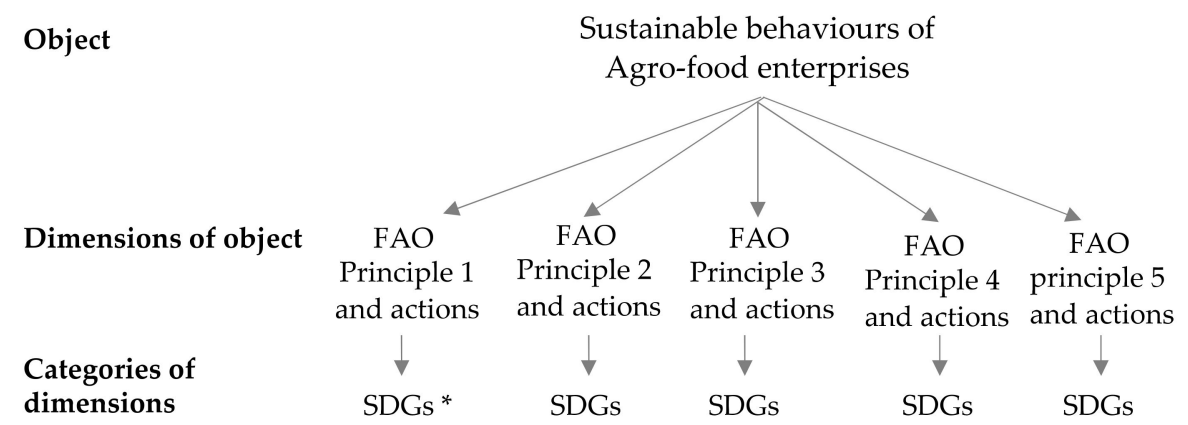

Figure 2. Articulation of object, dimensions, and categories. * Each SDG on each FAO's action gives a contribution according to the FAO framework [2].

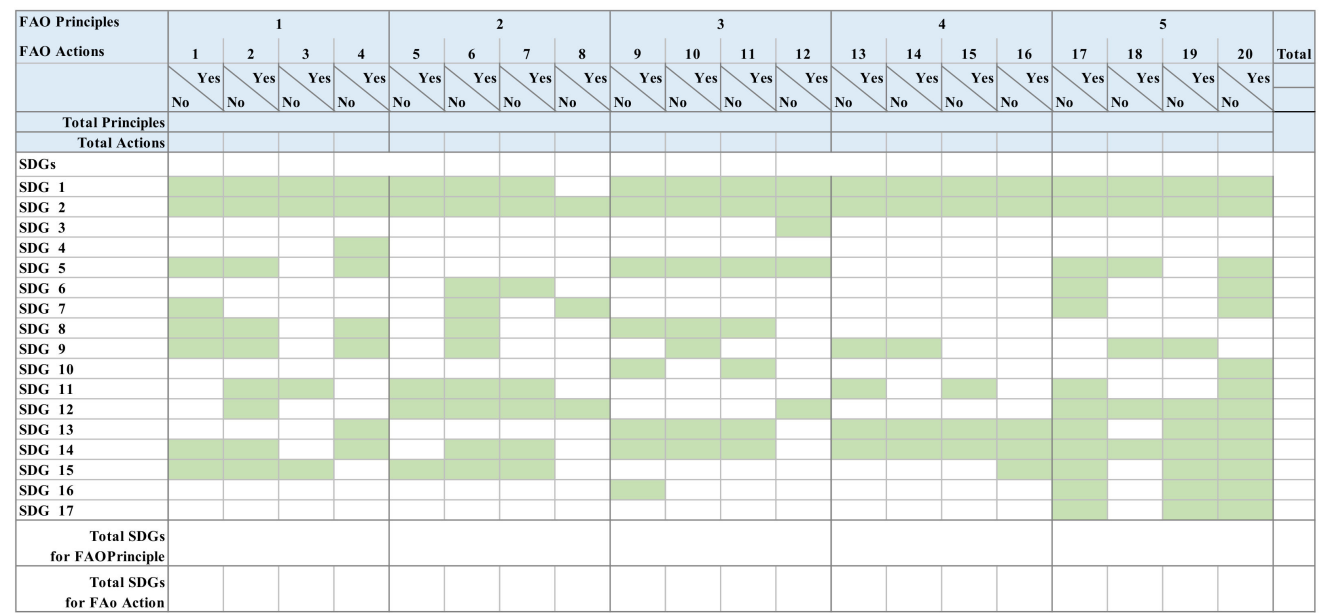

Figure 3. Contribution of FAOs to SDGs, according to FAO's framework [2].

Information on the AFBs' behaviours was collected based their descriptions on their websites. More precisely, we focused on information on sustainability real actions, tools and the performance of each company.

The drawing-up of the chart required a preliminary step and two subsequent steps.

In the preliminary step, for each firm's website, the presence or absence of a sustainability report and a section of the website dedicated to the sustainability field was noted. This was interpreted as the first signal of an AFBs' awareness of the importance of sustainability.

The next step aimed to describe the dimensions of the object. The behaviours (in conformity with the FAO's principles) of each selected AFB were individuated and related to each action indicated by the FAO guidelines [2]. The output was a dichotomous response variable (yes/no). Two researchers independently analysed the firms' websites. They looked for the presence or absence of a firm's behaviours according to the FAO's actions ('yes' for the presence of each behaviour and 'no' for its absence).

The sum of the positive responses was reported in the blue cell totals.

In the final step, for each selected AFB, we tried to relate each behaviour catalogued as previously described to the 17 SDGs of Agenda 2030 (analysis of categories of dimensions). In short, each FAO's action of the firm was ascribed to the SDG on which it has had an impact (i.e., by vertically selecting a cell among the green ones). Multiple behaviours of each firm related to one FAO action and the same SDG hold a value of one. Multiple behaviours for the same FAO's action and SDG were not considered.

Care was taken to ensure that all behaviours represented were real behaviours and not a simple declaration of intent. The presence of SA800 certification was interpreted as acting in line with action 9 (third principle) and SDG 8. Similarities among the independently 
generated data were noted, and after several iterations, a consensus was reached on the final coding of the major and minor themes. Finally, a third researcher checked for problems and inconsistencies; discrepancies were resolved through discussion.

The values attained by each firm in each cell of the chart shown in Figure 3 were added in the summary chart, shown in Figure 4.

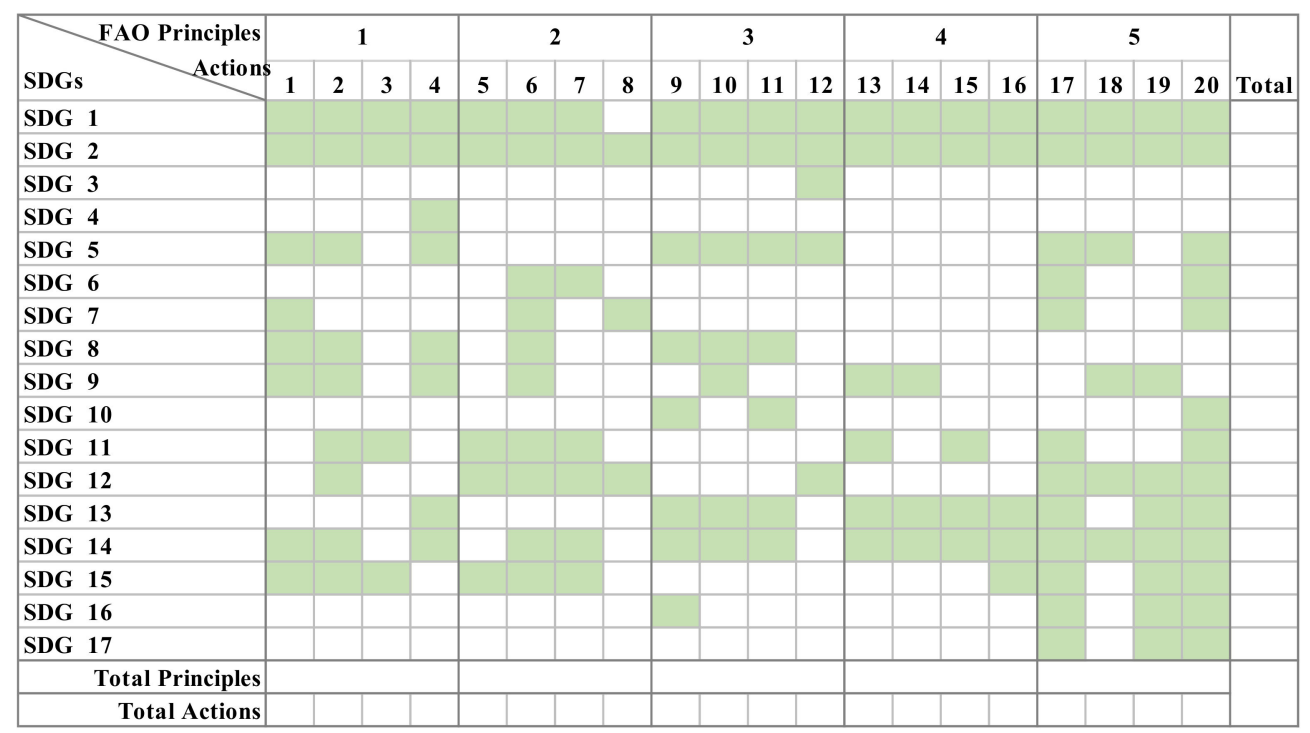

Figure 4. Summary chart of SMABs' behaviours.

It must be underlined that the analysis of the categories of dimensions concerns only SMABs under the role they play in the southern Italian economy.

The SMABs' behaviours were analysed based on the extended Abraham and Pingali framework [28], providing important insights worthy of further thought.

To better grasp the behaviour of the SMABs, a multi-criteria analysis (MCA) was applied to the sample.

MCA allows one to compare alternative courses of action based on multiple factors. Among various MCA methods, regime analysis (RA) was chosen to rank the five FAO principles based on how the selected firms promote sustainability. RA is an evaluation method suitable for handling sustainability problems owing to its applicability to complex scenarios [45]. This method allows the management of quantitative and qualitative information, which is why it was previously used to rank different sustainable development attributes [45-47]. RA requires defining a priori a distinct set of $i^{\text {th }}$ alternatives, evaluating each one's impact on a plurality of $j^{\text {th }}$ criteria for all criteria together $[48,49]$.

The first phase of RA concerns building an 'impact matrix' by assignment of the 'behaviour indices' $\left(p_{i j}\right)$ of each alternative with respect to each criterion, thereby adopting an appropriate judgement scale.

The second phase is devoted to constructing a 'regime matrix' through a pairwise comparison based on the 'behaviour indices' attributed to the 'impact matrix'.

The elements of the impact matrix are composed as follows:

$$
a_{i i^{\prime}, j}=+1 \text { if } p_{i j}>p_{i i^{\prime} j}, a_{i i^{\prime}, j}=-1 \text { if } p_{i j}<p_{i i^{\prime} j}, a_{i i^{\prime}, j}=0 \text { if } p_{i j}=p_{i i^{\prime} j},
$$

where for each comparison, $j$ is the value arising from comparing the two alternatives $i$ and $i^{\prime}$ according to the $j$ criterion. 
The final phase concerns obtaining the ranking of the alternatives. The aggregate priority of each alternative, i.e., the preference of option $i$ respect to alternative $i^{\prime}$ (considering all the criteria adopted) is expressed by the $C_{i}$ value:

$$
C_{i}=\frac{\sum_{i^{\prime}=1}^{n-1} c_{i i^{\prime}} \cdot j}{n-1}
$$

where $c_{i i^{\prime}}$ is the weight attributed to the criteria. $C_{i}$ is conveniently normalised so that it can be included between -1 and +1 . The alternative that reports the highest final value is the most attractive one according to the criteria set adopted.

In our study, the impact matrix is represented by the relationship between the 180 observed SMABs-i.e., the alternatives in the RA—and the five FAO principles. The behaviour indices reflect (for each firm) the frequency of 'yes' reported in the scheme shown in Figure 3. Since the highest frequency assessed was 8, we adopted a 1-9 judgement scale, i.e., $p_{i j}$ could assume a value from 1 (any presence of firm action related to the FAO principle) to 9 on the basis (8 actions).

The regime matrix was built based on Formula (1); it means that, in each cell, the value is equal to $+1,-1$, or 0 in cases of positive, negative, and null difference, respectively, between the behaviour indexes (from time to time) considered in the pairwise comparisons; finally, Formula 2 was applied to estimate the ranking among the FAO principles.

It is important to stress that in the MCA, for analytical purposes, the variables should be independent [48]. For this reason, the principles and actions of FAO were considered methodologically independent variables and interlinks among principles and actions were not investigated.

\section{Results}

A preliminary descriptive analysis was carried out to offer a snapshot of what is occurring in southern Italy regardless of the agricultural firms' size. This will lead to an understanding of the role of SMABs in achieving the objectives of sustainable development.

Findings showed that among the AFBs located in South Italy that had a website $(n=650)$, only $30 \%(n=193)$ implemented at least one action as defined by the FAO [2]. What emerges is a picture of the different attentions paid by firms to the issues of sustainable development. Only $38 \%$ of large AFBs (13 out of 34 ) implement these objectives, and the percentage is even lower in the case of SMABs (of which only $29 \%$ (180 out of 616) declared on the website to have put actions that positively impact sustainable development). Of these, $26 \%$ ( $n=8$ large firms and 42 SMABs) had a section of their respective websites dedicated to sustainability, although only seven in all (of which there were three large firms) had a sustainability report. These data can be interpreted as a sign of how many sustainability values are adopted by the SMABs.

Speaking about the actions taken in detail, Table 1 shows that $20 \%$ of AFBs take at least one action related to the protection and enhancement of natural resources (second principle), followed by $13 \%$ of firms being committed to improve livelihoods and foster inclusive economic growth (third principle). These overall rates take different values according to firm size, but the principles' positions do not change.

Looking at the actions taken by firms for each FAO principle, the findings show that the most reported action concerns the reduction in losses, encouraging 'reuse and recycling', and promoting sustainable consumption (action 8), followed by action 12 (improving nutrition and promoting balanced diets). 
Table 1. Number of AFBs taking at least one action per principle and action.

\begin{tabular}{|c|c|c|c|c|c|c|c|c|c|c|c|c|c|c|c|c|c|c|c|c|c|c|c|c|c|}
\hline \multirow{2}{*}{$\begin{array}{c}\text { FAO } \\
\text { Principles } \\
\text { FAO Actions }\end{array}$} & \multicolumn{5}{|c|}{$\begin{array}{c}1 . \\
\text { Increase Productivity } \\
\text { and Employment and } \\
\text { Value Addition in Food } \\
\text { Systems }\end{array}$} & \multicolumn{5}{|c|}{$\begin{array}{l}2 . \\
\text { Protect and Enhance } \\
\text { Natural Resources }\end{array}$} & \multicolumn{5}{|c|}{$\begin{array}{l}3 . \\
\text { Improve Livelihoods } \\
\text { and Foster Inclusive } \\
\text { Economic Growth }\end{array}$} & \multicolumn{5}{|c|}{$\begin{array}{l}4 . \\
\text { Enhance Resilience of } \\
\text { People, Communities, } \\
\text { and Ecosystems }\end{array}$} & \multicolumn{5}{|c|}{$\begin{array}{l}5 . \\
\text { Adapt Governance to } \\
\text { New Challenges }\end{array}$} \\
\hline & 1 & 2 & 3 & 4 & TP1 & 5 & 6 & 7 & 8 & TP2 & 9 & 10 & 11 & 12 & TP3 & 13 & 14 & 15 & 16 & TP4 & 17 & 18 & 19 & 20 & TP5 \\
\hline $\begin{array}{c}\text { N. AFBs } \\
\% \text { (on } 650 \text { ) }\end{array}$ & 3 & 23 & 6 & 35 & $\begin{array}{l}58 \\
8.9 \\
\end{array}$ & 31 & 21 & 33 & 90 & $\begin{array}{l}130 \\
20.0\end{array}$ & 38 & 4 & 8 & 51 & $\begin{array}{l}84 \\
12.9 \\
\end{array}$ & 1 & 0 & 25 & 7 & $\begin{array}{l}33 \\
5.1 \\
\end{array}$ & 4 & 4 & 0 & 0 & $\begin{array}{c}7 \\
1.1 \\
\end{array}$ \\
\hline $\begin{array}{l}\text { N. large } \\
\text { AFBs } \\
\% \text { (on } 34 \text { ) }\end{array}$ & 0 & 3 & 0 & 3 & $\begin{array}{l}5 \\
14.7\end{array}$ & 3 & 5 & 5 & 9 & $\begin{array}{l}13 \\
38.2\end{array}$ & 7 & 2 & 1 & 5 & $\begin{array}{l}8 \\
23.5\end{array}$ & 0 & 0 & 3 & 1 & $\begin{array}{l}3 \\
8.8\end{array}$ & 2 & 1 & 0 & 0 & $\begin{array}{c}2 \\
5.9\end{array}$ \\
\hline $\begin{array}{l}\text { N. SMABs } \\
\% \text { (on } 616 \text { ) }\end{array}$ & 3 & 20 & 6 & 32 & $\begin{array}{l}53 \\
8.6\end{array}$ & 28 & 16 & 28 & 81 & $\begin{array}{l}117 \\
19.0\end{array}$ & 31 & 2 & 7 & 46 & $\begin{array}{l}76 \\
12.3\end{array}$ & 1 & 0 & 22 & 6 & $\begin{array}{l}30 \\
4.9\end{array}$ & 2 & 3 & 0 & 0 & $\begin{array}{c}5 \\
0.8\end{array}$ \\
\hline
\end{tabular}

The total number of firms that take at least one action per principle is reported in the TP columns (TP = total for a given principle). This number can be lower than the sum of firms per single action because some firms can appear in more actions.

In order to describe the dimensions of the object and categories of dimensions with regard to SMABs, each of their behaviour was assessed according to the FAO's actions that impact the SDGs that have been listed. Table 2 summarizes the actions taken by the SMABs.

Table 2. Summary of actions performed by SMABs according to FAO's actions and SDGs.

\begin{tabular}{|c|c|c|c|c|c|c|c|c|c|c|c|c|c|c|c|c|c|c|c|}
\hline \multirow{2}{*}{$\begin{array}{l}\text { Principles } \\
\text { SDGs Actions }\end{array}$} & \multicolumn{3}{|c|}{ Principle 1} & \multicolumn{4}{|c|}{ Principle 2} & \multicolumn{3}{|c|}{ Principle 3} & \multicolumn{4}{|c|}{ Principle 1} & \multicolumn{4}{|c|}{ Principle 5} & \multirow{2}{*}{ Total } \\
\hline & 1 & 23 & 4 & 5 & 6 & 7 & 8 & 9 & 1011 & 12 & 13 & 14 & 15 & 16 & 17 & 18 & 19 & 20 & \\
\hline 1 & 2 & $0 \quad 0$ & 0 & 0 & 0 & 0 & & 1 & 13 & 0 & 0 & 0 & 0 & 2 & 0 & 0 & 0 & 0 & 9 \\
\hline 2 & 0 & $\begin{array}{ll}3 & 4\end{array}$ & 16 & 3 & 0 & 7 & 6 & 10 & $\begin{array}{ll}0 & 2\end{array}$ & 3 & 1 & 0 & & 0 & 1 & 0 & 0 & 0 & 56 \\
\hline 3 & & & & & & & & & & 34 & & & & & & & & & 34 \\
\hline 4 & & 0 & $\begin{array}{l}5 \\
2\end{array}$ & & & & & 2 & 0 & & & & & & & & & & 5 \\
\hline $\begin{array}{l}5 \\
6\end{array}$ & 0 & 0 & & & 4 & 0 & & & $\begin{array}{lll}0 & 0\end{array}$ & 0 & & & & & $\begin{array}{l}0 \\
0\end{array}$ & 0 & & $\begin{array}{l}0 \\
0\end{array}$ & 4 \\
\hline 7 & 1 & & & & 1 & & 30 & & & & & & & & 0 & & & 0 & 32 \\
\hline 8 & 0 & 13 & 9 & & 1 & & & 19 & $\begin{array}{ll}0 & 5\end{array}$ & & & & & & & & & & 47 \\
\hline 9 & 0 & 0 & 0 & & 0 & & & & 1 & & 0 & 0 & & & & & 0 & & 1 \\
\hline 10 & & & & & & & & 1 & 0 & & & & & & & & & & 1 \\
\hline 11 & & $\begin{array}{ll}0 & 0\end{array}$ & & 0 & & 0 & & & & & 0 & & 0 & & 0 & & & 0 & 0 \\
\hline 12 & & 5 & & 22 & 11 & 18 & 54 & & & 11 & & & & & 1 & 3 & 0 & 0 & 125 \\
\hline 13 & & & 1 & & & & & 0 & $\begin{array}{ll}0 & 0\end{array}$ & & 0 & 0 & 22 & 4 & 0 & & 0 & 0 & 27 \\
\hline 14 & 0 & 0 & 0 & & 0 & 1 & & 0 & $\begin{array}{ll}0 & 0\end{array}$ & & 0 & 0 & 0 & 0 & 0 & 0 & 0 & 0 & 1 \\
\hline 15 & 0 & $\begin{array}{ll}0 & 2\end{array}$ & & 4 & 1 & 2 & & & & & & & & 0 & 0 & & 0 & 0 & 9 \\
\hline 16 & & & & & & & & 0 & & & & & & & 0 & & 0 & 0 & 0 \\
\hline 17 & & & & & & & & & & & & & & & 0 & & 0 & 0 & 0 \\
\hline \multirow{2}{*}{ Total } & 3 & 216 & 33 & 29 & 18 & 28 & 90 & 33 & $\begin{array}{ll}2 & 10\end{array}$ & 48 & 1 & 0 & 22 & 6 & 2 & 3 & 0 & 0 & \multirow{2}{*}{355} \\
\hline & & 63 & & & 16 & & & & 93 & & & 29 & & & & 5 & & & \\
\hline
\end{tabular}

Using the Abraham and Pingali's [28] extended framework, we analysed the categories of dimensions, classifying the SMABs' behaviour from SDGs' viewpoint (Table 3).

Table 3. Number of actions reported for each sustainable development goal.

\begin{tabular}{|c|c|c|c|c|c|c|c|c|c|c|}
\hline \multirow[t]{2}{*}{ Goals } & \multicolumn{2}{|c|}{ Poverty } & \multicolumn{2}{|c|}{ Nutrition } & \multicolumn{2}{|c|}{ Social } & \multicolumn{2}{|c|}{ Environmental } & \multicolumn{2}{|c|}{ Residual } \\
\hline & Goal 1 & 9 & Goal 2 & 56 & Goal 4 & 5 & Goal 6 & 4 & Goal 11 & - \\
\hline & Goal 8 & 47 & Goal 3 & 34 & Goal 5 & 4 & Goal 7 & 32 & Goal 16 & - \\
\hline & & & & & Goal 10 & 1 & Goal 12 & 125 & Goal 17 & - \\
\hline & & & & & & & Goal 13 & 27 & Goal 9 & 1 \\
\hline & & & & & & & Goal 14 & 1 & & \\
\hline & & & & & & & Goal 15 & 9 & & \\
\hline Total & & 56 & & 90 & & 10 & & 198 & & 1 \\
\hline
\end{tabular}

The findings show that the environmental goals receive, without doubt, the greatest attention from the SMABs. This indicates that they understood that natural resources are the material basis of human society and made this the foundation of their primary sector activities. The maximum attention given to SDG 12 (responsible consumption and production) shows that the actions of the SMABs are inspired by the aims of reducing 
their environmental impact, promoting the use of renewable energy sources, and making responsible purchases. In particular, $43 \%$ of the behaviours concern the FAO action 8 . This action is also the most important in SDG 7, which is affordable clean energy (17\% of businesses). These data demonstrate companies' commitment to promoting their transition towards a sustainable energy system through technological investment in renewable energy resources.

The second priority was nutrition goals. The results show that companies' actions aimed at reducing hunger were mainly aimed at favouring their transformation to the SFA system by sharing knowledge, building capacities, and fostering participation in modern value chains (action FAO 4).

Finally, the poverty goals, and in particular the SDG 8 (decent work and economic growth), recorded a commitment from businesses for FAO action 9, which is 'empower people and fighting inequalities'.

The extent of the actions attributable to the social and residual SDGs are negligible.

The application of regime analysis allowed us to rank the FAO principles according to the behaviour of each SMAB that is summarised in Table 2 . Using a 180 (firms) $\times 5$ (principles) matrix and developing the method illustrated in the methodological section, we assessed that the second FAO principle, i.e., 'protect and enhance natural resources' was preferred over other principles (Table 4). This principle shows a score of about 0.7 , implying that, as a whole, SMABs that are expressly sustainability-oriented complied with it with a probability of approximately $70 \%$.

Table 4. Final ranking of Food and Agriculture Organization principles.

\begin{tabular}{lc}
\hline \multicolumn{1}{c}{ FAO Principles } & Probability \\
\hline 1. Increase productivity and employment and value addition in food systems & 0.490 \\
2. Protect and enhance natural resources & 0.682 \\
3. Improve livelihoods and foster inclusive economic growth & 0.548 \\
4. Enhance resilience of people, communities and ecosystems & 0.381 \\
5. Adapt governance to the new challenges & 0.351 \\
\hline
\end{tabular}

'Improve livelihoods and foster inclusive economic growth' ranks second, with an estimated score of 0.548 .

The other principles showed probabilities of less than $50 \%$. This is particularly surprising for the first FAO principle because increasing productivity and added value in the food system should represent the primary objectives of the SMABs. These firms probably tended not to declare this effort on the website or elsewhere because they considered it implicit.

\section{Discussion}

SMEs are considered to be the 'major engine' of economic growth and socio-economic development [50] and they play (now and in the near future) a leading role in SFA [51]. Therefore, this study aimed to investigate which sustainability actions are most important for the SMABs and which are neglected so as to provide policymakers with the basis for planning appropriate strategies to achieve all the SDGs of the 2030 Agenda.

Despite the variety of sustainability practices pursued by SMABs, the propensity for actions that lead to protect and improve natural resources prevails (65\%), disavowing previous studies that perceived SMEs as failures in relation to environmental sustainability due to their low take-up rates of sustainable business practices [52] (p. 172). This datum fits well with the CAP's aim of protecting natural resources, which, in the SMABs, is a worthy ally to push for SFA.

A possible explanation of this result suggests that SMABs, due to the rapid transformation of the agro-food system and the pressure on them to tackle environmental, health, and food safety problems [53], are more aware of both their environmental responsibility 
(ER) and competitive advantage derived from voluntary ER practices and their disclosure $[54,55]$. Indeed, organisations driven by sustainability competitiveness are prone to improve their performance related to energy and waste management, increase production and decrease sources of input, introduce eco-products, and implement ecological labelling and green marketing [56]. This interpretation of the results contrasts with previous studies in the Italian context, according to which SMEs understood the environmental responsibility as an added cost rather than a market opportunity, while not considering the market that is highly responsive to their environmental practices [57].

Within the second FAO principle, more actions were recorded for FAO action 8 (reduce losses, encourage reuse and recycle, and promote sustainable consumption). This indicates that SMABs have begun to understand that even if they are small, they contribute to pollution worldwide [52], and as producers, they will be central stakeholders in achieving an optimised, zero-waste production and distribution system [58] because they are likely to design business systems that reduce environmental impacts [59]. This propensity of SMABs bodes well for the transition towards the circular economy paradigm and meets the aim of the 'Circular Economy Package', which is the new action plan of Europe's new agenda for sustainable growth (EC 2018) and the Green Deal.

The second principle mainly considered is 'improve livelihoods and foster inclusive economic growth' (24\% of large AFBs and $42 \%$ of SMABs), which is primarily directed to reduce poverty and food insecurity in rural areas. This principle shares several aims with the CAP that supports farmers' income and adopts market measures, and seeks to ensure sustainable and inclusive rural development. The fact that SMABs are engaged in behaviours related to this FAO principle is of considerable importance.

First, because SMEs dominate the agro-industry sector and are a core component of any rural development strategy [60,61], our results can be read in the light of previous studies focused on social sustainability in agriculture according to which firms producing more social outputs are considered of great value [62]. Therefore, investments in the social dimension [63] in SMABs can find a perfect breeding ground for the success of policies aimed at promoting sustainable rural development, especially rural vitality and food security, which are considered among the most significant public goods from agriculture [64].

Second, we have noticed that many businesses have the tab 'territory' site menu, in several cases positioned before the 'about us' tab. This datum can be read according to two opposing interpretations. On the one hand, SMABs, especially Italian ones and producers of traditional food products, use 'territory' as a strategic resource in a fiercely competitive market, leveraging the synergistic link between authentic agro-food products and their region of origin $[65,66]$. On the other hand, it can be the expression of sincere interest in promoting its territory as a lever to increase the attention towards all local products and promote food and wine tourism. In this context, the producer feels part of a community and aims to contribute to its survival and growth.

Looking at the single FAO actions, the most important appears in the FAO action 12 (improve nutrition and promote balanced diets). The overwhelming majority of firms that have implemented policies/steps under this action have carried out nutrition education and awareness programs, promoting the consumption of locally grown nutritious food.

However, the commitment shown in action 9 (empower people and fight inequalities) is no less important. This action aims to provide rural firms with the tools and capacity to build resilient livelihoods. In this respect, many firms have activated programs to help small producers and young people enter networks that allow them to enter the market. This behaviour generates benefits that fall under social indicators related to the society as a whole (such as the quality of rural areas and contribution to local employment) [67] and can complement the concept of supply chain responsibility (SCR). Within the two-way relationship between supply chains (SCs) (that depend on community resources such as entrepreneurs) and the social well-being of communities (that build and maintain prosperity, thanks to the opportunity offered by SCs), the firms that participate in the agro-food supply chain reduce the producers' disadvantages and enhance the rural community's develop- 
ment. It is not just actions aimed at meeting external pressures, disclosing their "status of responsibility", maintaining their reputation and obtaining legitimacy to their operations and presence in the market [68-70]. SMABs also feel that they "have the responsibility to promote functional communities or community sustainability proactively" [71].

By focusing on the third most-widely reported principle (increase productivity and employment and value addition in food systems), on the one hand, SMABs are committed to creating the conditions for the producers' skills and knowledge so that they can participate in modern value chains (FAO action 4 ). On the other hand, just over $10 \%$ of the adopted behaviour related to FAO action 2 (connecting smallholders to markets). To make resilient and stable agro-food business, this system must encourage all the actors (and therefore, also smallholders) to cooperate, since, through cooperation, the agro-food system creates a new development process centred on sustainability, thereby creating value for territories and agro-food districts, promoting their uniqueness, and enhancing environmental protection and social cohesion [72]. In this sense, the policymakers' role is crucial in fostering such collaboration, particularly improving specific assistance to local AFBs for collective projects and spreading knowledge amongst other rural stakeholders [73].

Concerning the last two indicators reported, the lack of attention to principle 5 is not surprising (adapt governance to new challenges). Only four companies reported the FAO action 18 (strengthen innovation systems), having made investments in agricultural R\&D with collaboration between firms and universities. The least attention to principle 4 (enhancing the resilience of people, communities, and ecosystems) raises some questions.

On the one hand, the FAO actions 13, 14, and 16 may appear to be out of the reach of SMABs. On the other hand, only three large companies, but as many as 25 SMABs, have implemented actions aimed explicitly at reducing greenhouse gas emissions (FAO action 15-address and adapt to climate change). It is a sign that climate change is becoming a primary issue not only within the political agenda but also in businesses. In this context, education programs and outreach plans for SMABs can find fertile ground.

Turning our gaze towards SMABS' behaviours recorded based on the SDGs in which each FAO's action impacts, it appears that SMABs are more likely to adopt behaviours aimed at protecting and improving natural resources. The fact that there is only about $50 \%$ of probability that companies invest in actions aimed at increasing productivity and employment and adding value to food systems' raises doubts about the willingness or ability of companies to create networks in which skills and knowledge can be shared with small producers to develop their skills so as to connect small farms to markets.

Finally, by moving the analysis towards the SDGs, a significant finding was made: many SMABs are committed to achieving SDG 7, especially adopting innovations in the field of renewable energy. Its importance stems from the fact that the European Commission states that the clean energy supply for food and agriculture is crucial to deliver the European Green Deal. Once again, SMABs are proving to be agents of sustainable development.

\section{Final Remarks}

The aim of this study was to understand the behaviours of SMABs that promote the transition towards the SFA. In effect, the agro-food sector has always performed essential functions on the food, environmental, and social levels. Still, today, it is called and engaged in an even more complex effort if we consider that the future economy cannot ignore the social, economic, environmental, food, water equity, and energy issues and preserve biodiversity.

Our analysis has contributed to the literature by using the FAO approach outlined in 'transforming food and agriculture to achieve the SDGs' (2018), aiming to support and accelerate the transition to more sustainable agro-food systems. The previous literature investigates the agro-food system's actors' behaviours about single or multiple dimensions of sustainability or SDGs. However, as far as we know, no studies investigate specific behaviours according to FAO's actions. 
Another relevant contribution lies in investigating which categories of SDGs are greatly promoted by SMABs, bringing to light the important signs of their pivotal role in achieving effective Green Deal targets.

Finally, a further contribution lies in having carried out an analysis of sustainability actions of SMABs through the lens of digital disclosure, i.e., of firms that use online tools to communicate their commitment to sustainability. In fact, among the different types and tools available for external communication of corporate sustainability, online has experienced rapid growth in recent years [74] because it is "a privileged means of communication towards sustainable development, where information disclosed knows no border" [75] (p. 253). In this vein, the corporate website represents an important medium for voluntary sustainable disclosure, and their dialogical communication capabilities may be considered an indication of demonstrated willingness and preparedness to promote and support communication with external actors [76]. For that reason, the choice of the website as a tool for our investigation arises from the consideration that it is no longer a simple 'channel' among many, but often the strategic lever of dialogue and confrontation with the outside world.

This study had some limitations. First, it was based on a sample of southern Italian firms; thus, the results need to be tested in different areas and countries. Second, the study did not consider multiple behaviours relating to the same FAO's action and SDGs. Future research can account for such multiple behaviours as well as other common standards used by SMABs. Future research can also expand the study with direct interviews with companies to see if they take more actions than those posted on their website, with an undoubted advantage in terms of verifying our results. Finally, we used the FAO's principles as a diagnostic tool to interpret business operations. In this perspective, our findings do not allow one to give information about possible management implications on the prescriptive side. In effect, while providing a detailed overview of corporate behaviour, our findings are not directly able to give indications on the intentions that led to the adoption of observed behaviours by firms. However, we are conscious that the analysis of how pursuing the formal sustainability objectives can affect the company's management can be a valid next step of our research.

Author Contributions: Conceptualization, B.A., F.A.M., L.B., R.P., P.P. and R.F.; methodology, B.A., F.A.M., L.B., R.P., P.P. and R.F.; formal analysis, B.A., F.A.M.; investigation, B.A., L.B., R.P.; writingoriginal draft preparation, B.A., F.A.M., L.B., R.P.; writing-review and editing, B.A., F.A.M., L.B., R.P., P.P. and R.F; supervision, R.F., P.P.; project administration, P.P. All authors have read and agreed to the published version of the manuscript.

Funding: This research received no external funding.

Data Availability Statement: The Aida database—Bureau Van Dijk was used to select the sample of firms.

Conflicts of Interest: The authors declare no conflict of interest.

\section{References}

1. Campagnolla, C.; Rametsteiner, E.; Gutierrez, D. Sustainable Agriculture and Food Systems: Towards a Third Agricultural Revolution. Fome Zero Zero Hunger 2019, 140-157. [CrossRef]

2. FAO. Transforming Food and Agriculture to Achieve the SDGs: 20 Interconnected Actions to Guide Decision-Makers; FAO: Roma, Italy, 2018; ISBN 978-92-5-130626-0.

3. FAO. Sustainable Development Goals. Available online: http://www.fao.org/sustainable-development-goals/indicators/en/ (accessed on 27 April 2021).

4. FAO. Food and Agiculture in the 2030 Agenda 2016. Available online: http:/ /www.fao.org/3/i6105e/i6105e.pdf (accessed on 27 April 2021).

5. Ngenoh, E.; Kurgat, B.K.; Bett, H.K.; Kebede, S.W.; Bokelmann, W. Determinants of the Competitiveness of Smallholder African Indigenous Vegetable Farmers in High-Value Agro-Food Chains in Kenya: A Multivariate Probit Regression Analysis. Agric. Food Econ. 2019, 7, 2. [CrossRef]

6. Röös, E.; Fischer, K.; Tidåker, P.; Källström, H.N. How Well Is Farmers' Social Situation Captured by Sustainability Assessment Tools? A Swedish Case Study. Int. J. Sustain. Dev. World Ecol. 2019, 26, 268-281. [CrossRef] 
7. Terlau, W.; Hirsch, D.; Blanke, M. Smallholder Farmers as a Backbone for the Implementation of the Sustainable Development Goals. Sustain. Dev. 2019, 27, 523-529. [CrossRef]

8. Westman, L.; Luederitz, C.; Kundurpi, A.; Mercado, A.J.; Weber, O.; Burch, S.L. Conceptualizing Businesses as Social Actors: A Framework for Understanding Sustainability Actions in Small-and Medium-sized Enterprises. Bus. Strategy Environ. 2019, 28, 388-402. [CrossRef]

9. Zarbà, C.; Chinnici, G.; D'Amico, M. Novel Food: The Impact of Innovation on the Paths of the Traditional Food Chain. Sustainability 2020, 12, 555. [CrossRef]

10. Colman, P.; Harwell, J.; Found, P. Value Creation through Innovation in the Primary Sector. Int. J. Qual. Serv. Sci. 2020, 12, 475-487.

11. De Bernardi, P.; Azucar, D. A European Food Ecosystem: The EIT Food Case Study. In Innovation in Food Ecosystems; Springer: Cham, Switzerland, 2020; pp. 245-280.

12. Anríquez, G.; Stamoulis, K. Rural Development and Poverty Reduction: Is Agriculture Still the Key? 2007. Available online: https://ageconsearch.umn.edu/record/289048/ (accessed on 27 April 2021).

13. Asfaw, S.; Shiferaw, B.; Simtowe, F.; Lipper, L. Impact of Modern Agricultural Technologies on Smallholder Welfare: Evidence from Tanzania and Ethiopia. Food Policy 2012, 37, 283-295. [CrossRef]

14. Irz, X.; Lin, L.; Thirtle, C.; Wiggins, S. Agricultural Productivity Growth and Poverty Alleviation. Dev. Policy Rev. 2001, 19, 449-466. [CrossRef]

15. Kato, E.; Mekonnen, D.K.; Tiruneh, S.; Ringler, C. Sustainable Land Management and Its Effects on Water Security and Poverty: Evidence from a Watershed Intervention Program in Ethiopia; Intl Food Policy Res Inst: Washington, DC, USA, 2019; Volume 1811.

16. Wezel, A.; Casagrande, M.; Celette, F.; Vian, J.-F.; Ferrer, A.; Peigné, J. Agroecological Practices for Sustainable Agriculture. A Review. Agron. Sustain. Dev. 2014, 34, 1-20. [CrossRef]

17. Zeweld, W.; Van Huylenbroeck, G.; Tesfay, G.; Speelman, S. Smallholder Farmers' Behavioural Intentions towards Sustainable Agricultural Practices. J. Environ. Manag. 2017, 187, 71-81. [CrossRef]

18. Finco, A.; Bentivoglio, D.; Bucci, G. Lessons of Innovation in the Agrifood Sector: Drivers of Innovativeness Performances. Econ. Agro Aliment. 2018. [CrossRef]

19. Di Marco, L.; Obiettivi Di Sviluppo Sostenibile e Politiche Europee. Dal Green Deal al Next Generation EU. 2020. Available online: https://asvis.it/public/asvis2/files/Pubblicazioni/Quaderno_Obiettivi_di_sviluppo_sostenibile_e_politiche_europee. pdf (accessed on 27 April 2021).

20. Osservatorio Food Sustainability Cresce l'innovazione in Risposta Alle Sfide Di Sostenibilità Agroalimentare. 2019. Available online: https://www.osservatori.net/it/prodotti/formato/report/crescita-innovazione-sfide-sostenibilita-agroalimentare (accessed on 10 March 2021).

21. Coluccia, B.; Valente, D.; Fusco, G.; De Leo, F.; Porrini, D. Assessing Agricultural Eco-Efficiency in Italian Regions. Ecol. Indic. 2020, 116, 106483. [CrossRef]

22. Arru, B. An Integrative Model for Understanding the Sustainable Entrepreneurs' Behavioural Intentions: An Empirical Study of the Italian Context. Environ. Dev. Sustain. 2019, 22, 3519-3576. [CrossRef]

23. Del Baldo, M. Corporate Social Responsibility, Entrepreneurial Values and Transcendental Virtues in Italian SMEs. Int. J. Bus. Soc. Sci. 2014, 5, 25-51.

24. ISMEA. Rapporto Sulla Competitività Dell'agroalimentare Nel Mezzogiorno. 2019. Available online: http://www.ismeamercati. it/flex/cm/pages/ServeBLOB.php/L/IT/IDPagina/9942 (accessed on 27 April 2021).

25. Cohen, B.; Winn, M.I. Market Imperfections, Opportunity and Sustainable Entrepreneurship. J. Bus. Ventur. 2007, 22, 29-49. [CrossRef]

26. Jansson, J.; Nilsson, J.; Modig, F.; Hed Vall, G. Commitment to Sustainability in Small and Medium-sized Enterprises: The Influence of Strategic Orientations and Management Values. Bus. Strategy Environ. 2017, 26, 69-83. [CrossRef]

27. Moore, S.B.; Manring, S.L. Strategy Development in Small and Medium Sized Enterprises for Sustainability and Increased Value Creation. J. Clean. Prod. 2009, 17, 276-282. [CrossRef]

28. Abraham, M.; Pingali, P. Transforming smallholder agriculture to achieve the SDGs. In The Role of Smallholder Farms in Food and Nutrition Security; Springer: Cham, Switzerland, 2020; pp. 173-209.

29. Genç, R. The Importance of Communication in Sustainability \& Sustainable Strategies. Procedia Manuf. $2017,8,511-516$.

30. Gray, R.; Javad, M.; Power, D.M.; Sinclair, C.D. Social and Environmental Disclosure and Corporate Characteristics: A Research Note and Extension. J. Bus. Financ. Account. 2001, 28, 327-356. [CrossRef]

31. Adams, C.A.; Frost, G.R. Accessibility and Functionality of the Corporate Web Site: Implications for Sustainability Reporting. Bus. Strategy Environ. 2006, 15, 275-287. [CrossRef]

32. Da Giau, A.; Macchion, L.; Caniato, F.; Caridi, M.; Danese, P.; Rinaldi, R.; Vinelli, A. Sustainability Practices and Web-Based Communication: An Analysis of the Italian Fashion Industry. J. Fash. Mark. Manag. 2016, 20, 72-88. [CrossRef]

33. de Villiers, C.; van Staden, C. Shareholder Requirements for Compulsory Environmental Information in Annual Reports and on Websites. Aust. Account. Rev. 2011, 21, 317-326. [CrossRef]

34. Sharma, S.; Henriques, I. Stakeholder Influences on Sustainability Practices in the Canadian Forest Products Industry. Strateg. Manag. J. 2005, 26, 159-180. [CrossRef] 
35. Hasim, M.; Hashim, A.; Ariff, N.; Sapeciay, Z.; Abdullah, A. Commitment to Sustainability: A Content Analysis of Website for University Organisations. IOP Conf. Ser. Earth Environ. Sci. 2018, 117, 12046. [CrossRef]

36. Bosetti, L. Web-Based Integrated CSR Reporting: An Empirical Analysis. Symphonya Emerg. Issues Manag. 2018, 18-38. [CrossRef]

37. Capriotti, P. The world wide web and the social media as tools of CSR communication. In Handbook of Integrated CSR Communication; Springer: Cham, Switzerland, 2017; pp. 193-210.

38. Lodhia, S. Factors Influencing the Use of the World Wide Web for Sustainability Communication: An Australian Mining Perspective. J. Clean. Prod. 2014, 84, 142-154. [CrossRef]

39. Cassetta, E.; Monarca, U.; Dileo, I.; Berardino, C.D.; Pini, M. The Relationship between Digital Technologies and Internationalisation. Evidence from Italian SMEs. Ind. Innov. 2020, 27, 311-339. [CrossRef]

40. Kassem, E.; Trenz, O. Automated Sustainability Assessment System for Small and Medium Enterprises Reporting. Sustainability 2020, 12, 5687. [CrossRef]

41. Goswami, R.; Saha, S.; Dasgupta, P. Sustainability Assessment of Smallholder Farms in Developing Countries. Agroecol. Sustain. Food Syst. 2017, 41, 546-569. [CrossRef]

42. Perren, L.; Ram, M. Case-Study Method in Small Business and Entrepreneurial Research: Mapping Boundaries and Perspectives. Int. Small Bus. J. 2004, 22, 83-101. [CrossRef]

43. Leung, L. Validity, Reliability, and Generalizability in Qualitative Research. J. Fam. Med. Prim. Care 2015, 4, 324. [CrossRef]

44. Jansen, H. The Logic of Qualitative Survey Research and Its Position in the Field of Social Research Methods. Forum Qual. Soz. Forum Qual. Soc. Res. 2010, 11. [CrossRef]

45. Nijkamp, P.; Vindigni, G. Integrated Multicriteria Analysis for Sustainable Agricultural Policy Evaluation. Riv. Econ. Agrar. 1999, 53, 9-40.

46. Akgün, A.A.; van Leeuwen, E.; Nijkamp, P. A Multi-Actor Multi-Criteria Scenario Analysis of Regional Sustainable Resource Policy. Ecol. Econ. 2012, 78, 19-28. [CrossRef]

47. Idda, L.; Furesi, R.; Madau, F.A.; Rubino, C. The Italian Fishing and Aquaculture System in a Sustainable Development Perspective: A Multicriterial Approach to the Theme. In Proceedings of the 10th Congress European Association of Agricultural Economists (EAAE): Exploring Diversity in the European Agri-Food System, Zaragoza, Spain, 28-31 August 2002.

48. Munda, G.; Nijkamp, P.; Rietveld, P. Qualitative Multicriteria Evaluation for Environmental Management. Ecol. Econ. 1994, 10, 97-112. [CrossRef]

49. Nijkamp, P.; Rietveld, P.; Voogd, H. Multiple Criteria Analysis in Physical Planning; Elsevier: Amsterdam, The Netherlands, 1990.

50. Šebestová, J.; Sroka, W. Sustainable Development Goals and SMEs Decisions: Czech Republic vs. Poland. J. East. Eur. Cent. Asian Res. JEECAR 2020, 7, 39-50. [CrossRef]

51. SDSN. Transformative Changes of Agriculture and Food Systems. Prepared by the Thematic Group 7: Sustainable Agriculture and Food Systems; Sustainable Development Solutions Network: New York, NY, USA, 2013.

52. Battisti, M.; Perry, M. Walking the Talk? Environmental Responsibility from the Perspective of Small-business Owners. Corp. Soc. Responsib. Environ. Manag. 2011, 18, 172-185. [CrossRef]

53. Borsellino, V.; Schimmenti, E.; El Bilali, H. Agri-Food Markets towards Sustainable Patterns. Sustainability 2020, $12,2193$. [CrossRef]

54. Gallardo-Vázquez, D.; Sánchez-Hernández, M.I. Structural Analysis of the Strategic Orientation to Environmental Protection in SMEs. BRQ Bus. Res. Q. 2014, 17, 115-128. [CrossRef]

55. Panwar, R.; Nybakk, E.; Hansen, E.; Pinkse, J. The Effect of Small Firms' Competitive Strategies on Their Community and Environmental Engagement. J. Clean. Prod. 2016, 129, 578-585. [CrossRef]

56. Bansal, P.; Roth, K. Why Companies Go Green: A Model of Ecological Responsiveness. Acad. Manag. J. 2000, $43,717-736$.

57. Cantele, S.; Zardini, A. Is Sustainability a Competitive Advantage for Small Businesses? An Empirical Analysis of Possible Mediators in the Sustainability-Financial Performance Relationship. J. Clean. Prod. 2018, 182, 166-176. [CrossRef]

58. Jabbour, C.J.C.; de Jabbour, A.B.L.S.; Sarkis, J.; Filho, M.G. Unlocking the Circular Economy through New Business Models Based on Large-Scale Data: An Integrative Framework and Research Agenda. Technol. Forecast. Soc. Chang. 2019, 144, 546-552. [CrossRef]

59. Madau, F.A.; Arru, B.; Furesi, R.; Pulina, P. Insect Farming for Feed and Food Production from a Circular Business Model Perspective. Sustainability 2020, 12, 5418. [CrossRef]

60. Garcia-Alvarez-Coque, J.-M.; Mas-Verdu, F.; García, M.S. Determinants of Agri-Food Firms' Participation in Public Funded Research and Development. Agribusiness 2015, 31, 314-329. [CrossRef]

61. Jindřichovská, I.; Kubíčková, D.; Mocanu, M. Case Study Analysis of Sustainability Reporting of an Agri-Food Giant. Sustainability 2020, 12, 4491. [CrossRef]

62. Ait Sidhoum, A. Valuing Social Sustainability in Agriculture: An Approach Based on Social Outputs' Shadow Prices. J. Clean. Prod. 2018, 203, 273-286. [CrossRef]

63. Lebacq, T.; Baret, P.V.; Stilmant, D. Sustainability Indicators for Livestock Farming. A Review. Agron. Sustain. Dev. 2013, 33, 311-327. [CrossRef]

64. Cooper, T.; Hart, K.; Baldock, D. Provision of Public Goods through Agriculture in the European Union; Institute for European Environmental Policy London: London, UK, 2009. 
65. Festa, G.; Rossi, M.; Kolte, A.; Situm, M. Territory-Based Knowledge Management in International Marketing Processes-The Case of "Made in Italy" SMEs. Eur. Bus. Rev. 2020, 32, 425-442. [CrossRef]

66. Iaia, L.; Maizza, A.; Fait, M.; Scorrano, P. Origin Based Agro-Food Products: How to Communicate Their Experiential Value Online? Br. Food J. 2016. [CrossRef]

67. Diazabakana, A.; Latruffe, L.; Bockstaller, C.; Desjeux, Y.; Finn, J.; Kelly, E.; Ryan, M.; Uthes, S. A Review of Farm Level Indicators of Sustainability with a Focus on CAP and FADN. Ph.D. Thesis, Agro Paris Tech, Paris, France, 2014.

68. Kramer, M.R.; Porter, M. Creating Shared Value; FSG: Boston, MA, USA, 2011.

69. Maas, K.; Schaltegger, S.; Crutzen, N. Integrating Corporate Sustainability Assessment, Management Accounting, Control, and Reporting. J. Clean. Prod. 2016, 1-12. [CrossRef]

70. Stoian, D.; Donovan, J.; Fisk, J.; Muldoon, M.F. Value Chain Development for Rural Poverty Reduction: A Reality Check and a Warning. Enterp. Dev. Microfinanc. J. 2012, 23, 54. [CrossRef]

71. Liu, L.; Ross, H.; Ariyawardana, A. Community Development through Supply Chain Responsibility: A Case Study of Rice Supply Chains and Connected Rural Communities in Central China. Sustainability 2020, 12, 927. [CrossRef]

72. Contini, C.; Marotta, G.; Torquati, B. Multi-Actor Approaches to Implement Cooperative Strategies and Value Chains Based on Sustainability. Agric. Food Econ. 2020, 8, 7. [CrossRef]

73. Cisilino, F.; Vanni, F. Agri-Environmental Collaborative Projects: Challenges and Perspectives in Italy. Econ. AGRO Aliment. 2019, 459-479. [CrossRef]

74. Lundquist Lundquist CSR Online Awards. 2017. Available online: https://lundquist.it/wp-content/uploads/2017/11/CSR_ OA_2017_interattivo-1.pdf (accessed on 15 April 2021).

75. Carvalho, F.; Santos, G.; Gonçalves, J. The Disclosure of Information on Sustainable Development on the Corporate Website of the Certified Portuguese Organizations. Int. J. Qual. Res. 2018, 12, 253-276.

76. Thimm, H.; Rasmussen, K.B. Website Disclosure of Environmental Compliance Management-The Case of European Production Companies. J. Environ. Stud. Sci. 2020. [CrossRef] 